\title{
Dawn singing behavior of a tropical bird species, the Pied Bush Chat Saxicola caprata
}

\author{
Vinaya K umar Sethi, Dinesh B hatt* and A mit K umar
}

Avian Diversity and Bioacoustics Lab., Department of Zoology and Environmental Science, Gurukula Kangri University, Haridwar 29404 (Uttarakhand), INDIA

*Corresponding author: E-mail: dineshharidwar@gmail.com

Received: May 7, 2012; Revised received: J uly 15, 2012; Accepted: September 30, 2012

\begin{abstract}
This paper aims to study the structure and pattern of dawn song in a tropical avian species, the Pied Bush Chat (Saxicola caprata) in Haridwar ( $29^{\circ} 55^{\prime} \mathrm{N}, 7^{\circ} 08^{\prime} \mathrm{E}$; Uttarakhand, India) in 2009. Males delivered complex dawn chorus on daily basis during only breeding season (February to July). The dawn song bout was made up of a number of distinct sections called song types. Each song type consisted of a series of similar or dissimilar units referred to as elements. Song type length averaged $1.43 \pm 0.23 \mathrm{sec}$ and did not differ significantly among males. The average number and types of elements in a song type were observed $8.15 \pm 1.64$ and $8.01 \pm 1.56$, respectively.In more than $80 \%$ of observations, song types were delivered with immediate variety and males did not follow any definite sequential pattern of song delivery. Males sang continuously for about $30 \mathrm{~min}$ at high rates during dawn. Males performed continuous dawn singing throughout the breeding season and seemed to interact vocally through counter-singing for extended period. Observations suggest that dawn song delivery in Pied Bush Chat plays an important role in maintenance and adjustment of social relationship among neighbouring males.
\end{abstract}

Keywords: Dawn song, Pied Bush Chat, Saxicola caprata, Song characteristics, Song rate

\section{INTRODUCTION}

Among songbirds, male song is a vocal display that birds use to convey contextual information about motivation levels (Gottfried et al., 1985). The breeding season of many avian species is characterized by particularly high singing activity at dawn, referred to as the dawn chorus (Catchpole and Slater, 1995). The functions of this dawn chorus have been speculated on extensively and hypotheses such as environmental pressures, hormonerelated cycles and social functions (Staicer et al., 1996) have been proposed. Social functions can be split into two groups following the generally accepted dual function of song, territorial defense and mate attraction (McGregor, 1991; Catchpole and Slater, 1995).

Studies have shown that many of the signals used by song birds in sexual contexts are honest advertisements of several kinds of quality of the senders (Johnstone, 1995). There are evidences suggesting that male songs have many attributes that could affect the behaviour of females and rival males (Catchpole and Slater, 1995). For example, song type length reflects competitive ability of males Hoopoe (U pupa epops) (Vivaldi et al., 2004). Females of several species have also been found to prefer some special song types (Vallet and Kreutzer, 1995; Foerster, 2002); these may be ones that are difficult to produce so that only males of high quality can master them(Slater, 2003). Studies also suggest that the receivers that focus solely on physical song characteristics of a male may gain information about the male's willingness to escalate a fight (Dabelsteen and Pedersen, 1992); its previous experience or age (Lambrechts and Dhondt, 1986; Welling et al., 1995); current body condition (Godfrey and Bryant, 2000) and social rank in a network of territorial individuals (Otter et al., 1997). Besides this, song characteristics of male may also help female assessing male's quality (Kempenaers et al., 1997; Poesel et al., 2004). For example, song characteristics might reveal that good quality males are better at parental care (Forslund and Part, 1995), possess better territories (Catchpole, 1986), are less infected with parasites and/or are more immune against pathogens (Saino et al., 2003; Garamszegi et al., 2005).

In order to understand the function of song in any avian species or to investigate the role of song characteristic(s) of a bird species in conveying behavioural information to the listeners, the basic requirement is to generate fundamental data on the structure of that song bird. In fact, fundamental data on the song characteristics have potential to answer many outstanding research questions of avian acoustic communication system (Lein, 2007). However, such studies are scanty, at least in tropical region (Morton, 1996; Slater and Mann, 2004). For example, in India, situated with the tropical monsoon belt, systematic studies on bird song behavior are almost 
negligible (Bhatt et al., 2000; Sethi and Bhatt, 2008). Consequently, we largely lack fundamental data on song characteristics and singing behavior of almost all the Indian songbirds. This paper aims to fill one of these gaps by describing the structure and pattern of dawn song behaviour of a tropical avian species, the Pied Bush Chat (Saxicola caprata).

\section{MATERIALS AND METHODS}

Study species: The Pied Bush Chat (Order Passeriformes, Family Muscicapidae) is a tropical songbird that occurs discontinuously from Transcaspia and the Indian subcontinent to South East Asia, the Philippines, Indonesia, New Guinea and New Britain (Ali and Ripley, 1998). It is found in open habitats including scrub, grassland and cultivated areas. Males use dawn chorus from their respective territories during the breeding season (Ali and Ripley, 1998). Territory size of Pied Bush Chat ranges from $2327.7 \mathrm{~m}^{2}$ to $5229.3 \mathrm{~m}^{2}$ with an average of $3941.5 \pm 951.1 \mathrm{~m}^{2}(\mathrm{n}=8)$ (pers. obs.). This species appears to be socially monogamous, and each pair produces two to three broods during each breeding season (Bell and Swainson, 1985).

Study area, song recording and analysis: This study was carried out from February to July 2009 in agricultural fields and open grounds with scattered bushes at Haridwar (29 $55^{\prime} \mathrm{N}$ and $78^{\circ} 08^{\prime} \mathrm{E}$ ), Uttarakhand, India. We recorded the dawn singing behaviour of male Pied Bush Chats $(\mathrm{N}=12)$ from a color banded population. Male territories were mapped by noting locations of singing and boundary encounters. We visited each territory before dawn and recorded the entire chorus.

Songs were recorded from 4 to $6 \mathrm{~m}$ without influencing the singing behaviour of males. In this study, the dawn song characteristics that were investigated included song type length, minimum and maximum frequencies of song types, composition of song type and song rate. The Sennheiser ME 67 directional microphone attached to a Marantz PMD 670 portable solid state was used as sound recorder (D\& M Holdings Inc., Kanagawa, Japan). Songs were saved to a computer as Wav files with input sampling frequency of $24000 \mathrm{~Hz}$ and sample format of 16 bit. Spectrograms were prepared with Avisoft SASLab Pro 4.1 software (Specht, 2002). The song characteristics were compared among males using one way ANOVA and mean \pm SD were calculated (Zar, 1999).

\section{RESULTS}

Males of the Pied Bush Chat delivered complex song bouts during dawn. Day time singing activities of males were also observed however; contrary to dawn singing, day time songs were unpredictable and delivered only occasionally. Males started their dawn chorus in quite darkness (about an hour before sun rise). Three males initially moved from their roost sites to song perches prior to singing while remaining nine males started dawn singing from their overnight roost.

Males used relatively low perches for dawn singing varying from 0 (ground) to $3.0 \mathrm{~m}$ with a mean height of $0.7 \pm 0.6 \mathrm{~m}(\mathrm{~N}=74)$. This was in marked contrast to perches used during daytime singing that were usually near the top of the canopy of trees, on the edge of a building or on an electric pole with a mean height of $4.8 \pm 1.7 \mathrm{~m}$ (range: 1.4 to $8 \mathrm{~m}, \mathrm{~N}=47$ ). In more than $25 \%$ of the 74 observations males sang from the ground during dawn singing, whereas males never perched on ground while singing during daytime. Most dawn song events ended when the male stopped singing and flew away from the site, sometimes beginning foraging.

Males recorded on multiple dates used the same small regions, often near an edge of a territory, for dawn singing. Neighbouring males seemed to interact vocally often performing counter-singing for extended periods throughout the breeding period. Males sang continuously for about $30 \mathrm{~min}$ (median $=30.5 \mathrm{~min}$; range $=15-46 \mathrm{~min}$ ) at high rates during dawn. Rates measured from recordings with a minimum length of $10 \mathrm{~min}$ of song bout $(\mathrm{N}=240)$ averaged $15.8 \pm 3.6$ songs $/ \mathrm{min}$ and did not differ significantly among males $(\mathrm{F}=1.486, \mathrm{df}=9,230, \mathrm{P}$ $=0.15$ ).

The songs of the Pied Bush Chat were found to be highly varied and complex, composed of different song types (Fig. 1). Based on visual inspection of the spectrograms, a total of 94 song types were identified in the dawn song repertoires of twelve males. Observed dawn song repertoire sizes ranged between 13 to 29 song types with a mean value of $22.6 \pm 5.4$ song types $(\mathrm{N}=12$ males). Males delivered dawn song bouts with immediate variety viz. in

Table 1. Dawn song characteristics of song types $(\mathrm{N}=94)$ in male Pied Bush Chat (Saxicola caprata) $(\mathrm{N}=12)$.

\begin{tabular}{lccc}
\hline Variable & M inimum & M aximum & M ean \pm SD \\
\hline Song type length $(\mathrm{sec})$ & 0.73 & 2.22 & $1.43 \pm 0.23$ \\
Minimum frequency $(\mathrm{kHz})$ & 1.50 & 2.39 & $1.92 \pm 0.18$ \\
Maximum frequency $(\mathrm{kHz})$ & 4.26 & 7.68 & $5.93 \pm 0.55$ \\
Number of elements in a Song type & 5 & 14 & $8.15 \pm 1.64$ \\
Types of elements in a Song type & 5 & 14 & $8.01 \pm 1.56$ \\
\hline
\end{tabular}




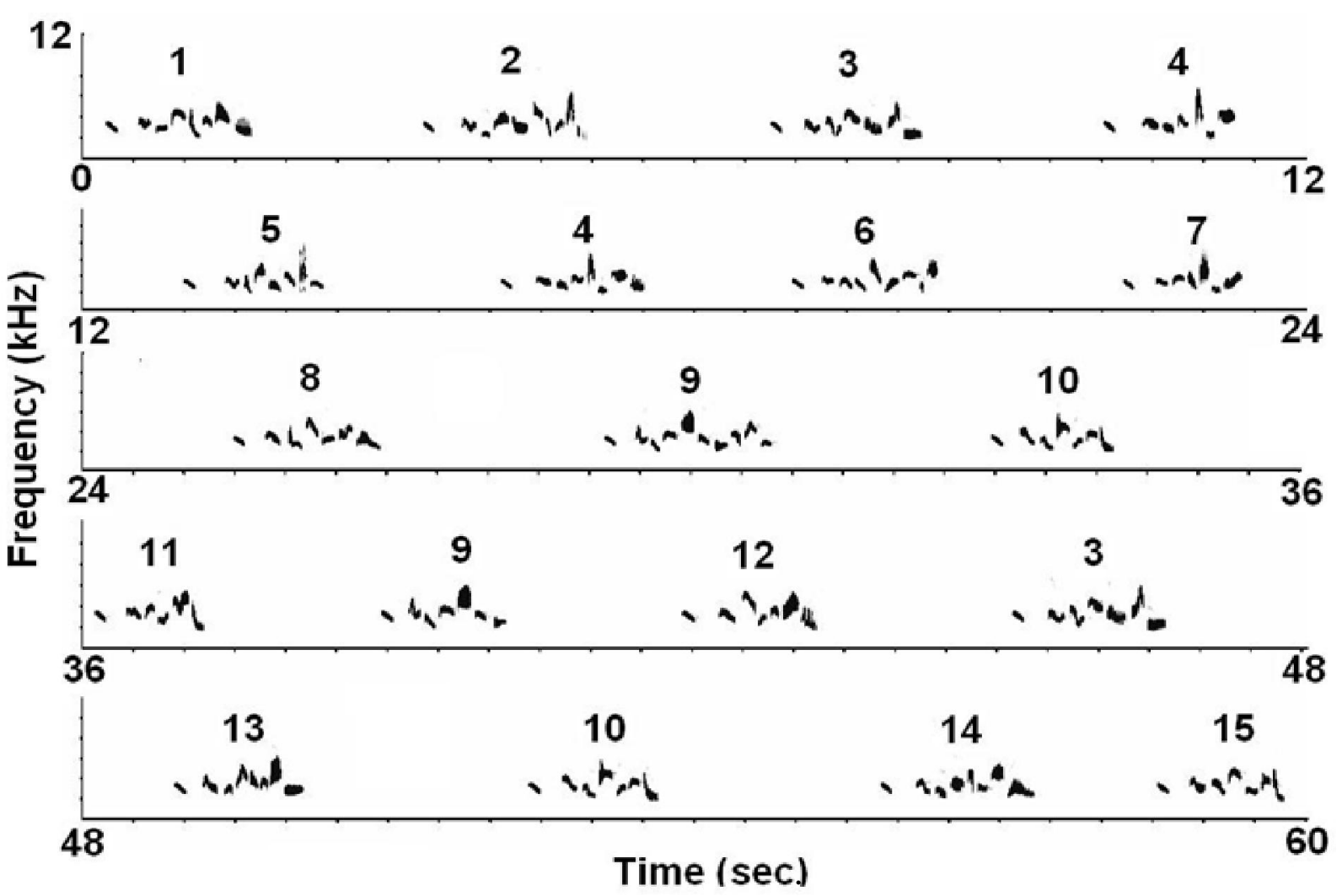

Fig. 1. Spectrogram of a $60 \mathrm{sec}$ segment of dawn song bout of a male Pied B ush C hat (Saxicola caprata). Each panel continues from the panel immediately above. Song types are identified by number in the each panel.

more than $80 \%$ observations, males did not repeat a given song type before switching to another. That is, song types were sung with continuous variety, however, without following any sequential pattern (Fig. 1).

Basic dawn song characteristics of Pied Bush Chat have been given in Table 1 . Song type length ranged from 0.7 to $2.2 \mathrm{sec}$ and the length of the majority of song types (more than 85\%) fell between 1.2 and $1.6 \mathrm{sec}$ (Fig. 2). On comparing the song length among males, we did not observe any statistically significant difference $(\mathrm{F}=0.593$, $\mathrm{df}=11,260, \mathrm{P}=0.833)$. The average minimum and maximum frequencies of song types were found as $1.92 \pm 0.18 \mathrm{kHz}$ and $5.93 \pm 0.55 \mathrm{kHz}$., respectively. The average number and types of elements in a song type were observed as $8.15 \pm 1.64$ and $8.01 \pm 1.56$, respectively (Table 1 ). The song types of Pied Bush Chat were complex in structure i.e. the bird used different types of elements in a single song type. The number of different types of elements in song types ranged from 5 to 14 and more than $75 \%$ song types were composed of 7-9 types of elements (Table 2).

\section{DISCUSSION}

Results indicated that males of the Pied Bush Chat sang maximally, and on a daily basis during dawn as compared to other times of the day. Song delivery as dawn chorus is a common feature of a number of song birds (Catchpole and Slater, 1995). It has been reported that during the dawn chorus, territorial male song birds sing intensively within signaling range of several conspecific males and can therefore be considered members of a busy communication network. The more or less continuous singing over a long period of time under standardized stimulus conditions makes the dawn song a potentially important information source both for simple receivers and eavesdroppers (Poesel et al., 2004). Moreover, dawn appears to be the best time for singing because the hindrances to acoustic communication are least at this time of the day (Brown and Handford, 2003).

Males Pied Bush Chat used relatively low perches for dawn singing, noticeably different from the higher perches used during daytime singing, suggesting that dawn and daytime singing may have different functions. Like the Pied Bush Chat, territorial males of Chipping Sparrow (Spizella passerina) (Liu, 2004) and Buff-breasted Flycatcher (E mpidonax fulvifrons) (Lein, 2007) have also been reported to perform dawn singing from the ground or low perches and in both the species day time songs are delivered from higher perches. In Pied Bush Chat the dawn songs appear to be associated with close-range social interaction between neighbouring males, whereas the day song might function for long-distance broadcasting for female attraction as suggested by Liu (2004) for Chipping Sparrows.

Our study showed that males Pied Bush Chat delivered 


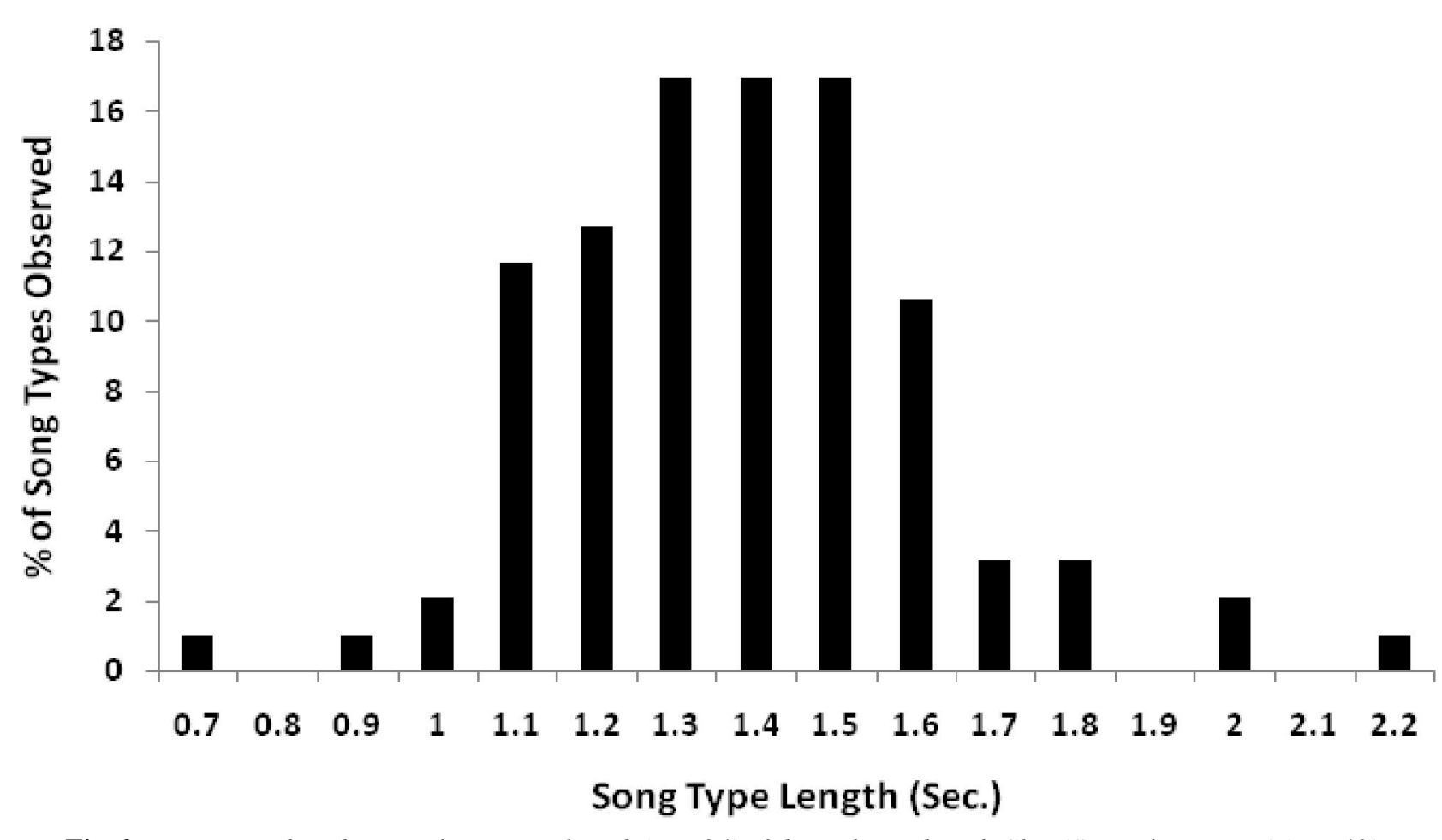

Fig. 2. F requency distribution of song type length $(N=94)$ of the male Pied B ush C hat (Saxicola caprata) $(N=12)$.

dawn chorus at high rate. Dawn song delivery at high rate at or near territorial boundaries apparently remained unchanged throughout the breeding season. Also, males observed trespassing into adjacent territories were immediately chased by the resident male and, shortly thereafter, both males began to sing. We frequently observed males interacting through counter-singing for extended periods, suggesting the importance of dawn songs for maintenance and adjustment of social relationship among neighbours. That is, males used dawn singing to communicate with their close neighbours, to announce and assess their strength or willingness to defend the territory, or to challenge neighbours on a daily

Table 2. Frequency of song types $(\mathrm{N}=94)$ built with different types of elements in the dawn song of the male Pied Bush Chat (Saxicola caprata) $(\mathrm{N}=12)$.

\begin{tabular}{ccc}
\hline $\begin{array}{c}\text { No. of differ ent } \\
\text { element types }\end{array}$ & $\begin{array}{c}\text { Total song } \\
\text { types observed }\end{array}$ & $\begin{array}{c}\% \text { of } \\
\text { song types }\end{array}$ \\
\hline 5 & 4 & 4.26 \\
6 & 5 & 5.32 \\
7 & 31 & 32.98 \\
8 & 24 & 25.53 \\
9 & 17 & 18.09 \\
10 & 7 & 7.45 \\
11 & 4 & 4.26 \\
12 & 0 & 0.00 \\
13 & 1 & 1.06 \\
14 & 1 & 1.06 \\
\hline Total & 94 & 100.00 \\
\hline
\end{tabular}

basis throughout the breeding season, as reported in social dynamic hypothesis by Staicer et al. (1996).

Female removal experiment in Pied Bush Chat has also indicated that males direct their dawn chorus to their neighbours instead of their mates (Sethi et al., 2011a). Recent studies have also suggested that birds may use their songs in a more complex or subtle way to interact with specific receivers, particularly in a territorial system where the relationships between territorial neighbours could be mediated by songs used during close-range interaction (McGregor, 1993; Smith, 1997; Todt and Naguib, 2000).

In the present study the songs of Pied Bush Chat males were found highly varied consisted of repertoires of different song types. The song repertoire size was found comparable with the size observed in a previous study carried out in the same study area on a different population of male Pied Bush Chats (Sethi et al., 2011b). It has been found that there are two extreme ways in birds for the presentation of repertoire during a singing performance (Hartshorne, 1973). Males may repeat a song type many times before introducing another, called 'eventual variety' (Borror, 1987; Bhatt et al., 2000). Alternatively, they may sing with 'immediate variety', where successive song types are different from one another (Borror and Reese, 1956; Eens et al., 1989). The present study reveals that the male Pied Bush Chats sang more than $80 \%$ of their songs with immediate variety.

The most obvious feature of dawn singing by Pied Bush Chat was the high song rate that did not differ significantly among males. Similarly, there were no 
statistically significant difference in song length among males. Song rate and song length have been known to reflect male quality in birds. For example, females prefer males with a higher song rate in many bird species such as Pied Flycatcher (Ficedula hypoleuca) (Gottlander, 1987), European Starling (Sturnus vulgaris) (Gentner and Hulse, 2000) and House Finch (Carpodacus mexicanus) (Nolan and Hill, 2004). Similarly, males which sing longer song types survive better and have a higher individual lifetime reproductive success (Lambrechts and Dhondt, 1986). Such conclusions can be drawn only with a comparative study on males of different mating status i.e. mated vs. unmated. However, in the present study all the subjects were mated and thus, further comparative study is needed to understand the significance of song rate and song length in the reproduction of Pied Bush Chat, if any.

\section{ACK NOW LEDGEMENTS}

We thank the Head, Department of Zoology and Environmental Science, Gurukul Kangri University Haridwar, India for providing infrastructure. Many thanks to Mr. Shivchand for assisting us in song recordings. We are grateful to Prof. M. Ross Lein, Department of Biological Sciences, University of Calgary, Canada for his valuable feedback on an earlier version of this manuscript. Department of Science and Technology (Government of India) is gratefully acknowledged for funding this study (Project sanction no. SR/SO/AS/73/ 2006).

\section{REFERENCES}

Ali, S. and Ripley, S.D. (1998). Handbook of the birds of India and Pakistan (volume 9: robins to wagtails). Oxford University Press, New Delhi, India.

Bell H.L., Swainson, G.W. (1985). The colonization, ecology and breeding of the pied stonechat Saxicola caprata at Port Moresby, Papua New Guinea. Ibis, 127: 74-83.

Bhatt, D., Kumar, A., Singh, Y. and Payne, R.B. (2000). Territorial songs and calls in Oriental Magpie Robin Copsychus saular is. Current Science, 78: 722-728.

Borror, D.J. (1987). Song in the White-eyed Vireo. Wilson Bulletin, 99: 377-397.

Borror, D.J. and Reese, C.R. (1956). Vocal gymnastics in Wood Thrush songs. O hio J ournal of Science, 56: 177-182.

Brown, T.J. and Handford, P. (2003). Why birds sing at dawn: the role of consistent song transmission. Ibis, 145: 120-129.

Catchpole, C.K. (1986). Song repertoires and reproductive success in the great reed warbler Acrocephalus arundinaceus. Behavioral Ecology and Sociobiology, 19: 439-445.

Catchpole, C.K. and Slater, P.J.B. (1995). Bird song: biological themes and variations. Cambridge University Press, Cambridge.

Dabelsteen, T. and Pedersen, S.B. (1992). Song features essential for species discrimination and behaviour assessment by male blackbirds (Turdus merula). Behaviour, 121: 259-287.

Eens, M., Pinxteen, R. and Verheyen, R.F. (1989). Temporal and sequential organization of song bouts in the Starling. Ardea, 77: 75-86.

Foerster, K. (2002). Extra-pair paternity in the blue tit Parus caeruleus. Doctoral thesis, Zoological Institute, University of Vienna, Vienna.

Forslund, P. and Part, T. (1995). Age and reproduction in birds - hypotheses and tests. Trends in Ecology and Evolution, 10: $374-378$.

Garamszegi, L.Z., Heylen, D., Møller, A.P., Eens, M. and de Lope, F. (2005). Age dependent health status and song characteristics in the barn swallow. Behavioral E cology, 16: 580-591.

Gentner, T.Q. and Hulse, S.H. (2000). Female European Starling preference and choice for variation in conspecific male song. Animal Behavior, 59: 443-458.

Godfrey, J.D. and Bryant, D.M. (2000). State-dependent behaviour and energy expenditure: an experimental study of European robins on winter territories. J ournal of Animal Ecology, 69: 301-313.

Gottfried, B.M., Andrews, K. and Haug, M. (1985). Breeding robins and nest predators: Effect of predator types and defense strategy on initial vocalization patterns. Wilson Bulletin, 97: 183-190.

Gottlander, K. (1987). Variation in the song rate of the male Pied Flycatcher (Ficedula hypoleuca): Causes and consequences. Animal Behavior, 35: 1037-1043.

Hartshorne, C. (1973). Born to sing. Indiana University Press, Bloomington.

Johnstone, R.A. (1995). Sexual selection, honest advertisement and the handicap principle: Reviewing the evidence. Biology Review, 70: 1-65.

Kempenaers, B., Verheyen, G.R. and Dhondt, A.A. (1997). Extrapair paternity in the blue tit Parus caeruleus: Female choice, male characteristics, and offspring quality. Behavioural E cology, 8: 481-492.

Lambrechts, M.M. and Dhondt, A.A. (1986). Male quality, reproduction and survival in the great tit (Parus major) Behavioral Ecology and Sociobiology, 19: 57-63.

Lein, M.R. (2007). Patterns of dawn singing by Buff-breasted Flycatchers. J ournal of Field O rnithology, 78: 343-351.

Liu, W.C. (2004). The effect of neighbors and females on dawn and daytime singing behaviors by male chipping sparrows. Animal Behavior, 68: 39-44.

McGregor, P.K. (1991). The singer and the song: On the receiving end of bird song. Biology Review, 66: 57-81.

McGregor, P.K. (1993). Signalling in territorial systems: a context for individual identification, ranging and eavesdropping. Philosophical Transactions of the Royal Society of London, Series B, 338: 1-8.

Morton, E.S. (1996). A comparison of vocal behavior among tropical and temperate passerine birds. In: D.E. Kroodsma and E.H. Miller (Eds.), Ecology and evolution of acoustic communication in birds (pp 258-268), New York: Comstock Press.

Nolan, P.M. and Hill, G.E. (2004). Female choice for song characteristics in the House Finch. Animal Behavior, 67: 403-410.

Otter, K., Chruszcz, B. and Ratcliffe, L. (1997). Honest advertisement and song output during the dawn chorus of black-capped chickadees. Behavioral E cology, 8: 167-173. 
Poesel, A., Dabelsteen, T. and Pedersen S.B. (2004). Dawn song of male blue tits as a predictor of competitiveness in midmorning singing interactions. Acta Ethologica, 6: 65-71.

Saino, N., Galeotti, P., Sacchi, R. and Møller, A.P. (2003). Humoral immune response in relation to senescence, sex, and sexual ornamentation in the barn swallow (Hirundo rustica). J ournal of Evolutionary Biology, 16: 1127-1134.

Sethi, V.K. and Bhatt, D. (2008). Call repertoire of an endemic avian species, the Indian Chat Cercomela fusca. Current Science, 94: 1173-1179.

Sethi, V.K., Bhatt, D. and Kumar, A. (2011a). The effect of mate removal on dawn singing behaviour in male pied bush chats. Current Zoology, 57: 72-76.

Sethi, V.K., Bhatt, D. and Kumar, A. (2011b). Song repertoire size of the Pied Bushchat Saxicola caprata. Current Science 100: 302-304.

Slater, P.J.B. (2003). Fifty years of bird song research: a case study in animal behaviour. A nimal Behaviour, 65: 633-639.

Slater, P.J.B. and Mann, N.I. (2004). Why do the females of many bird species sing in the tropics? J ournal of Avian Biology, 35: 1-6.

Smith, W.J. (1997). The behavior of communicating, after twenty years. In: D.H. Owings, M.D. Beecher and N.S. Thompson (Eds.), Perspectives in Ethology (pp 1-23), New
York: Plenum Press.

Specht, R. (2002). Avisoft-SASLab Pro Sound Analysis and Synthesis Laboratory (a PC-software). Avisoft Bioacoustics (http://www.avisoft.com), Berlin.

Staicer, C.A., Spector, D.A. and Horn, A.G. (1996). The dawn chorus and other diel patterns in acoustic signaling. In: D.E. Kroodsma and E.H. Miller (Eds.), Ecology and evolution of acoustic communication in birds (pp 426-453), New York: Cornell University Press.

Todt, D. and Naguib, M. (2000). Vocal interactions in birds: the use of song as a model in communication. Advance Studies in Behavior, 29: 247-296.

Vallet, E. and Kreutzer, M. (1995). Female canaries are sexually responsive to special song phrases. Animal Behaviour, 49: 1603-1619.

Vivaldi, M.M., Palomino, J.J. and Soler, M. (2004). Strophe length in spontaneous songs predicts male response to playback in the Hoopoe U pupa epops. Ethology, 110: 351362.

Welling, P., Koivula, K. and Lathi, K. (1995). The dawn chorus is linked with female fertility in the willow tit Parus montanus. J ournal of Avian Biology, 26: 241-246.

Zar, J.H. (1999). Biostatistical Analysis. Prentice-Hall, New Jersey. 